\title{
The Rietveld refinement studies of pyromorphite-vanadinite and mimetite-vanadinite solid solution series
}

\author{
Urszula Solecka, Sylwia Zelek, Tomasz Bajda \\ AGH University of Science and Technology, Faculty of Geology, Geophysics and Environmental Protection, Department of \\ Mineralogy, Petrography and Geochemistry; al. A. Mickiewicza 30,30-059 Krakow, Poland; e-mail: ujanicka@agh.edu.pl
}

(C) 2016 Authors. This is an open access publication, which can be used, distributed and reproduced in any medium according to the Creative Commons CC-BY 4.0 License requiring that the original work has been properly cited.

Mimetite $\mathrm{Pb}_{5}\left(\mathrm{PO}_{4}\right)_{3} \mathrm{Cl}$, vanadinite $\mathrm{Pb}_{5}\left(\mathrm{VO}_{4}\right)_{3} \mathrm{Cl}$ and pyromorphite $\mathrm{Pb}_{5}\left(\mathrm{PO}_{4}\right)_{3} \mathrm{Cl}$ belong to the apatite supergroup. They form in oxidation zones of lead ore deposits. These minerals have high thermal stability (Dong et al. 2002) and low solubility (Flis et al. 2011) thus they have many applications. Pyromorphite and mimetite are especially used to immobilize lead in contaminated soils and hazardous industrial wastes (Ma et al. 1993, Kim et al. 2005, Bajda et al. 2007), it is therefore important to know the impact of various factors on their properties.

Crystal structure of apatites corresponds to the general formula $\mathrm{M}_{5}\left(\mathrm{TO}_{4}\right)_{3} \mathrm{X}$, where $\mathrm{M}$ are bivalent cations distributed on two distinct crystallographic sites, $\mathrm{TO}_{4}$ is a trivalent oxyanion and $\mathrm{X}$ is a monovalent anion. The structure and chemistry of apatite allow for numerous substitutions of metal cation and anionic complexes (Hughes \& Rakovan 2002, Pan \& Fleet 2002). It was found that substitutions cause variations in the unit cell parameters and chemical properties of these minerals (Botto et al. 1997), but there are no articles presenting variations in the whole series. Therefore, these researches present changes of lattice parameters for pyromorphite-vanadinite and mimetite-vanadinite solid solution series.

Pyromorphite, mimetite and vanadinite crystallize in hexagonal symmetry (the space group $\mathrm{P}_{3} / \mathrm{m}$ ) (Dong et al. 2002, Pan \& Fleet 2002). They form continuous isomorphic series. The aim of the study was to examine how lattice parameters of pyromorphite-vanadinite and mimetite-vanadinite solid solutions series change with increasing vanadium content and characterize these phenomena.

Crystallographic studies were conducted on synthetic pyromorphite, mimetite and vanadinite and minerals with intermediate compositions $\mathrm{Pb}_{5}\left(\mathrm{TO}_{4}\right)_{3} \mathrm{Cl}$, where $\mathrm{T}=\mathrm{P}+\mathrm{V}$ or As $+\mathrm{V}$, of various $\mathrm{P} / \mathrm{V}$ or As/V ratios. Samples were analyzed by $\mathrm{X}$-Ray diffraction (XRD) using RIGAKU Smartlab X-Ray diffractometer with $\mathrm{Cu}$ radiation in a $10^{\circ}$ to $110^{\circ} 2 \Theta$ range at a step size of $0.022 \Theta$ and a rate of $2 \mathrm{~s}$ per step. The phase identification was carried out using the X'Rayan computer program and X-ray standard patterns in the form of ICDD files (card 19-0701, 19-0683 and 43-1461). The unit-cell refinement and Rietveld structure refinement were made using the FullProf Suite computer program package (Rodriguez-Carvajal 1993).

The Rietveld refinement has shown systematic changes in unit cell parameters of studied samples depending on their chemical composition. Dimensions of unit cell parameters of pyromorphite-vanadinite solid solution series increase linearly with the substitution of vanadate ions in the structure of pyromorphite. Lattice parameter "a" increase in the range of 9.987-10.325 , while lattice parameter " $c$ " increase in the range of 7.33-7.343 $\AA$. In case of the mimetite-vanadinite solid solution series, lattice parameter "a" increase (10.251-10.325 ̊̊ range), whereas lattice 
parameter "c" decrease (7.442-7.343 ̊̊ range) linearly with the substitution of vanadate ions in the structure of mimetite. This situation indicates the equivalent position of the tetrahedral $\mathrm{TO}_{4}$ in the structure of lead apatite.

The project was financed with resources of the $\mathrm{Na}$ tional Science Centre, Poland, granted based on decision no. DEC-2013/09/N/ST10/00677.

\section{REFERENCES}

Bajda T., Szmit E. \& Manecki M., 2007. Removal of As(V) from solutions by precipitation of mimetite $\mathrm{Pb}_{5}\left(\mathrm{AsO}_{4}\right)_{3} \mathrm{Cl}$. [in:] Pawłowski L., Dudzińska M. \& Pawłowski A. (eds), Environmental Engineering, Taylor \& Francis Group, London, 119-124.

Botto I.L., Barone V.L., Castiglioni J.L. \& Schalamuk I.B., 1997. Characterization of a natural substituted pyromorphite. Journal of Materials Science, 32, 6549-6553.
Dong Z., White T.J., Wei B. \& Laursen K., 2002. Model Apatite Systems for the Stabilization of Toxic Metals: I, Calcium Lead Vanadate. Journal of the American Ceramic Society, 85, 10, 2515-2522.

Flis J., Manecki M. \& Bajda T., 2011. Solubility of pyromorphite $\mathrm{Pb}_{5}\left(\mathrm{PO}_{4}\right)_{3} \mathrm{Cl}$-mimetite $\mathrm{Pb}_{5}\left(\mathrm{AsO}_{4}\right)_{3} \mathrm{Cl}$ solid solution series. Geochimica et Cosmochimica Acta, 75, 1858-1868.

Hughes J.M. \& Rakovan J., 2002. The Crystal Structure of Apatite, $\mathrm{Ca}_{5}\left(\mathrm{PO}_{4}\right)_{3}(\mathrm{~F}, \mathrm{OH}, \mathrm{Cl})$. Reviews of Mineralogy and Geochemistry, 48 (1), 1-12.

Kim J.Y., Dong Z. \& White T.J., 2005. Model Apatite Systems for the Stabilization of Toxic Metals: II, Cation and Metalloid Substitutions in Chlorapatites. Journal of the American Ceramic Society, 88, 5, 1253-1260.

Ma Q.Y., Traina S.J, Logan T.J. \& Ryan J.A., 1993. In situ lead immobilization by apatite. Environmental Science and Technology, 27, 1803-1810.

Pan Y. \& Fleet M.E., 2002. Compositions of the Apatite-Group Minerals: Substitution Mechanisms and Controlling Factors. Reviews of Mineralogy and Geochemistry, 48, 2, 13-49.

Rodriguez-Carvajal, J., 1993. Recent advances in magnetic structure determination by neutron powder diffraction. Physica B: Condensed Matter, 192, 1-2, 55-69. 